\title{
The use of innovative payment mechanisms for gene therapies in Europe and the USA
}

\author{
Jesper Jørgensen ${ }^{1}$ (iD) \& Panos Kefalas*,1 (iD \\ ${ }^{1}$ Cell \& Gene Therapy Catapult, 5th Floor Uncommon, 1 Long Lane, London SE1 4PG, UK \\ *Author for correspondence: Tel.: +44 0203728 9500; panos.kefalas@ct.catapult.org.uk
}

Innovative reimbursement mechanisms have long been considered potential solutions to the data uncertainty associated with one-off, high-value gene therapies that have long-term therapeutic potential, combined with limited supporting evidence at launch. The launches of increasing numbers of such gene therapies in Europe and the USA in the past 5 years provide valuable exemplars of how innovative reimbursement mechanisms are used by healthcare system decision makers in practice. This review details the use of such reimbursement schemes for recently launched gene therapies in key European countries and the USA, and shows that they are more widespread in Europe than in the USA. Although innovative payment schemes are increasingly used across countries, differences in healthcare system structures (e.g., single- vs multi-payer systems) and willingness to pay mean that decision makers in different countries have different incentives to manage uncertainties around long-term, real-world product value.

First draft submitted: 27 October 2020; Accepted for publication: 18 March 2021; Published online: 13 April 2021

Keywords: chimeric antigen receptor T-cell therapy $\bullet$ gene therapy $\bullet$ health technology assessment $\bullet$ innovative payment mechanisms $\bullet$ market access $\bullet$ outcomes-based reimbursement

The decade from 2010 to 2020 saw many exciting breakthroughs in medical sciences, with several advanced and regenerative medicines like cell and gene therapies obtaining regulatory marketing approval in Europe and in the USA. Common for many of these gene therapies is that they often target small patient populations with high clinical unmet need, and that they can deliver potentially long-term (or even lifelong) benefits to patients through a single (one-off) administration.

While the advent of these innovative therapies was eagerly awaited by patients and clinicians, it did not come without challenges for manufacturers, or for healthcare systems. High manufacturing and delivery costs, combined with low patient numbers have in several instances seen the prices of these therapies exceed hundreds of thousands of dollars. From the healthcare system point of view, this creates several challenges, for example, managing the short-term budget impact, and assessing and ensuring value for tax-payer money, while also enabling patient access to therapeutic innovation. Health technology assessment (HTA) bodies and reimbursement authorities face a particularly challenging balancing act when presented with expensive therapies that have potentially lifelong health benefits, but are only supported by short-term clinical data at launch. The resulting decision uncertainty surrounding the real-world value of such new therapies, and whether the price points are justifiable, is something that payers and HTA bodies have grappled with for years, also prior to these advanced medicines launching. However, what sets single-administration therapies apart from conventional medicines (using repeated administrations to achieve or sustain the therapeutic benefit), is that with the latter it is possible to simply discontinue treatment (thus also further payments) if patients do not respond. Conversely, in the case of single-administration therapies, the option to discontinue treatment if the desired outcome is not achieved is not available, and this exacerbates the uncertainty around real-world value and the financial implications of adopting these therapies.

Traditionally, payers have often managed decision uncertainty through simple discounts; however, as the pipeline of highly priced, innovative therapies has grown, so have the calls for innovative pricing and reimbursement mechanisms. These issues have been widely discussed in the context of new cell and gene therapies launching [16], including the concept of tying the payment mechanism to patient outcomes achieved in the real world [7]. Outcomes-based reimbursement (OBR) schemes have gradually become more widespread over the past 10 years, 
Table 1. Date and regulatory approved therapeutic indications for single-administration gene therapies marketed in Europe and the USA between 2016 and 2020.

\begin{tabular}{|c|c|c|c|}
\hline Therapy & European regulatory approval for marketing ${ }^{\dagger}$ & US regulatory approval for marketing $\ddagger$ & Ref. \\
\hline Strimvelis $^{\circledR}$ & $\begin{array}{l}26 \text { May 2016: } \\
\text { Severe combined immunodeficiency due to } A D A \text { gene deficiancy } \\
\text { ( } A D A-S C I D), \text { where no suitable HLA-matched related stem cell } \\
\text { donor is available }\end{array}$ & $\mathrm{N} / \mathrm{A}$ & [15] \\
\hline $\begin{array}{l}\text { Kymriah }^{\circledR} \\
\text { (tisagenlecleucel) }\end{array}$ & $\begin{array}{l}22 \text { August 2018: } \\
\text { - Patients up to } 25 \text { years of age with B-cell ALL that is refractory, in } \\
\text { relapse post transplant or in second or later relapse } \\
\text { - Adult patients with R/R DLBCL after two or more lines of ST }\end{array}$ & $\begin{array}{l}30 \text { August 2017: } \\
\text { Patients up to } 25 \text { years of age with B-cell precursor } \\
\text { ALL that is refractory or in second or later relapse } \\
1 \text { May 2018: } \\
\text { R/R large B-cell lymphoma after two or more lines of } \\
\text { systemic therapy including DLBCL not otherwise } \\
\text { specified, high grade B-cell lymphoma and DLBCL } \\
\text { from follicular lymphoma }\end{array}$ & [16-18] \\
\hline $\begin{array}{l}\text { Yescarta }{ }^{\circledR} \\
\text { (axicabtagene } \\
\text { ciloleucel) }\end{array}$ & $\begin{array}{l}23 \text { August 2018: } \\
\text { - Adults with R/R DLBCL, after two or more lines of ST } \\
\text { - Adults with R/R primary mediastinal large B-cell lymphoma, after } \\
\text { two or more lines of ST }\end{array}$ & $\begin{array}{l}18 \text { May 2018: } \\
\text { Adult patients with R/R large B-cell lymphoma after } \\
\text { two or more lines of ST }\end{array}$ & {$[19,20]$} \\
\hline $\begin{array}{l}\text { Luxturna }^{\circledR} \\
\text { (voretigene } \\
\text { neparvovec) }\end{array}$ & $\begin{array}{l}22 \text { November 2018: } \\
\text { Adult and pediatric patients with vision loss due to inherited } \\
\text { retinal dystrophy caused by confirmed bi-allelic RPE65 mutations } \\
\text { with sufficient viable retinal cells }\end{array}$ & $\begin{array}{l}19 \text { December 2017: } \\
\text { Patients with confirmed } \\
\text { bi-allelic RPE65 mutation-associated retinal dystrophy } \\
\text { (patients must have viable retinal cells as determined } \\
\text { by the treating physician) }\end{array}$ & {$[21,22]$} \\
\hline $\begin{array}{l}\text { Zynteglo }{ }^{\circledR} \\
\text { (betibeglogene } \\
\text { autotemcel) }\end{array}$ & $\begin{array}{l}29 \text { May 2019: } \\
\text { Patients } 12 \text { years and older with transfusion-dependent } \beta \\
\text { thalassemia who do not have a } \beta 0 / \beta 0 \text { genotype, for whom HSC } \\
\text { transplantation is appropriate but a HLA-matched related donor is } \\
\text { not available }\end{array}$ & $\mathrm{N} / \mathrm{A}$ & [23] \\
\hline $\begin{array}{l}\text { Zolgensma }^{\circledR} \\
\text { (onasemnogene } \\
\text { abeparvovec) }\end{array}$ & $\begin{array}{l}18 \text { May 2020: } \\
\text { - Patients with } 5 q \text { SMA Type } 1 \text { with a bi-allelic mutation in the } \\
\text { survival motor neuron (SMN) } 1 \text { gene, or } \\
\text { - } 5 q \text { SMA with a bi-allelic mutation in the SMN1 gene and up to } 3 \\
\text { copies of SMN2 gene }\end{array}$ & $\begin{array}{l}24 \text { May 2019: } \\
\text { Pediatric patients less than } 2 \text { years of age with SMA } \\
\text { with bi-allelic mutations in the SMN1 gene }\end{array}$ & {$[24,25]$} \\
\hline $\begin{array}{l}\text { Tescartus } \\
\text { (brexucabtagene } \\
\text { autoleucel) }\end{array}$ & $\mathrm{N} / \mathrm{A}$ & $\begin{array}{l}24 \text { July 2020: } \\
\text { Adult patients with } \mathrm{R} / \mathrm{R} \text { mantle cell lymphoma }\end{array}$ & [26] \\
\hline \multicolumn{4}{|c|}{$\begin{array}{l}\text { †Through the EMA. } \\
\text { ¥Through the US FDA in the USA. } \\
\text { ADA-SCID: Severe combined immunodeficiency due to adenosine deaminase deficiency; ALL: Acute lymphoblastic leukemia; DLBCL: Diffuse large B-cell lymphoma; HSC: Hematopoietic } \\
\text { stem cell; N/A: Not applicable; R/R: Relapsed or refractory; SMA: Spinal muscular atrophy; ST: Systemic therapy. }\end{array}$} \\
\hline
\end{tabular}

and we have previously detailed the role OBR played in the launch of the two chimeric antigen receptor T (CAR-T) cell therapies Kymriah ${ }^{\circledR}$ (tisagenlecleucel) and Yescarta ${ }^{\circledR}$ (axicabtagene ciloleucel) in major European countries (i.e., France, Germany, Italy, Spain and the United Kingdom) [8]. While there are recent examples of studies looking at the application of OBR schemes to different types of therapies in different geographies [9-14], we are not aware of any that look specifically at high-value, single-administration gene therapies, comparing the OBR approaches taken in major European countries and the USA. As more gene therapy products are coming to market both in Europe and the USA, we believe it is worth taking a closer look at the use of innovative pricing and payment mechanisms on both sides of the Atlantic, to get a view of how payers in different geographies manage the decision uncertainty these products can present.

The objective of this article is to provide a top-level overview of the use of OBR and innovative access schemes for gene therapies launched in France, Germany, Italy, Spain, England and the USA in the past 5 years. Based on our findings, we provide a comparison of the approaches adopted in countries with single payer/public health insurance (European countries) and multipayer systems (the USA). More specifically, we focus on the therapies detailed in Table 1.

This review is not intended as an exhaustive detail for each of the different therapies in terms of HTA, pricing, reimbursement and market access schemes across different administrative levels in the above-mentioned countries. Rather, it is a collection of exemplars (as per the final half of 2020) providing real-world, cross-country learnings about market access approaches for high-cost, gene therapies with data uncertainty at launch; availability of relevant evidence in the public domain was a driver in determining exemplars chosen. 
We applied a targeted evidence review of secondary sources available in the public domain, with preference being given to materials from official sources, for example, relevant regulatory competent authorities, HTA bodies, government health bodies, reimbursement authorities and health insurers (public and private). Our research set out to detail the use of innovative pricing or payment schemes, according to:

- The type of scheme applied, in other words, whether financial implications are tied to;

- Rebates or payments based on therapeutic performance in treated patients over time; these are often linked to individual patient data (IPD) in the real world setting;

- Health technology reassessments informing future coverage/reimbursement decisions and price adjustments (also referred to as coverage with evidence development [CED]);

- These are often linked to assessments of data at cohort level collected in the real-world setting post launch as well as long-term follow-ups of pivotal clinical trials;

- The type of outcomes collected (where available) for the purposes of assessing product performance in the target patient population, as deemed most relevant by the by different HTA bodies, and/or payers;

- The data collection infrastructure used (where available);

- Details on the payment mechanism tied to product performance (where available).

Data collection was undertaken during the months from August to October 2020, and collated in a Microsoft Excel spreadsheet.

In the below, we detail exemplars of OBR schemes used for gene therapies across major European countries and the USA.

\section{Europe}

The healthcare systems in France, Germany, Italy, Spain and England are predominantly single-payer systems, with public health insurance covering either the entire, or the vast majority of the population. Whereas countries such as Italy and Spain are more decentralized (leaving the operationalization and provision of healthcare services to autonomous regions), all 5 countries have national HTA bodies and reimbursement authorities that make binding decisions in terms of which treatments are to be reimbursed in the public healthcare system, and under what conditions [27]. In the below, we provide exemplars of innovative reimbursement schemes implemented across the five major European countries.

\section{France}

CED is a notable feature of market access for innovative therapies in France, importantly also because it can apply before marketing authorization, through the 'Temporary Authorization for Use' (Autorization Temporaire d'Utilization, [ATU]) early access program [28]. The ATU program allows reimbursed access before marketing authorization approval to therapies that hold particular therapeutic promise and are not currently available through clinical trials in France [29]. Under the ATU program (and until the HTA and pricing negotiations have been completed with national authorities), the manufacturer can set the price freely, subject to an annual spending cap and the potential for postlaunch paybacks [30,31]. The cohort ATU scheme is used to collect real-world data on safety and efficacy in clinical practice in French patients [32], and this information is used subsequently to complement clinical data from pivotal trials to inform HTA and reimbursement decisions.

However, CED is also used by French reimbursement authorities to manage decision uncertainty beyond launch through conditions leveraged on reimbursement in the French healthcare system. Both Kymriah and Yescarta were part of the cohort ATU program; however, in the Transparency Committee's (TC) assessments (from December 2018), both therapies were subject to additional data collection post launch, to inform annual health technology reassessments [33,34] (see Table 2).

Key outcomes that are to be collected for Kymriah and Yescarta include survival, remission status, disease progression and adverse events, and these are to be recorded at 28 days, 100 days, 6 months and every subsequent 6 months after injection, and reported by hospitals on a quarterly basis [35]. Data collection is facilitated through the Lymphoma Academic Research Organisation (LYSARC) data platform [36].

CED was applied as a condition for reimbursement also for Zynteglo ${ }^{\circledR}$ when the French HTA body (the TC) published its evaluation from March 2020. The TC stated that given the uncertainties with respect to the 
Table 2. Exemplars of innovative reimbursement mechanisms used for gene therapies in France.

\begin{tabular}{|c|c|c|c|}
\hline Therapy & Access scheme used & Nature and source of data collected for access scheme & Ref. \\
\hline $\begin{array}{l}\text { Kymriah }^{\circledR} \\
\text { (tisagenlecleucel) }\end{array}$ & $\begin{array}{l}\text { CED: annual health technology reassessments based } \\
\text { on additional cohort data }\end{array}$ & $\begin{array}{l}\text { - Data from routine use in French patients, as collected through } \\
\text { the LYSARC registry } \\
\text { - Data from long-term follow-up from pivotal trials }\end{array}$ & {$[35,36]$} \\
\hline $\begin{array}{l}\text { Yescarta }{ }^{\circledR} \text { (axicabtagene } \\
\text { ciloleucel) }\end{array}$ & $\begin{array}{l}\text { CED: annual health technology reassessments based } \\
\text { on additional cohort data }\end{array}$ & $\begin{array}{l}\text { - Data from routine use in French patients, as collected through } \\
\text { the LYSARC registry } \\
\text { - Data from long-term follow-up from pivotal trials }\end{array}$ & {$[35,36]$} \\
\hline $\begin{array}{l}\text { Zynteglo }^{\circledR} \text { (betibeglogene } \\
\text { autotemcel) }\end{array}$ & $\begin{array}{l}\text { CED: health technology reassessments after a } \\
\text { maximum of } 3 \text { years based on additional cohort data }\end{array}$ & $\begin{array}{l}\text { - All available data on use, efficacy and tolerance including: } \\
\text { - Data from a de novo registry to detail all treated French } \\
\text { patients } \\
\text { - The studies required by the EMA as part of the conditional } \\
\text { marketing authorization }\end{array}$ & {$[37,38]$} \\
\hline
\end{tabular}

\begin{tabular}{|c|c|c|c|}
\hline Therapy & Access scheme used & Nature and source of data collected for access scheme & Ref. \\
\hline $\begin{array}{l}\text { Luxturna }{ }^{\circledR} \text { (voretigene } \\
\text { neparvovec) }\end{array}$ & $\begin{array}{l}\text { CED: health technology reassessment based on } \\
\text { additional cohort data }\end{array}$ & $\begin{array}{l}\text { CED based on data from EMA safety study and long-term } \\
\text { follow-up data from pivotal trial (to be collected until } 31 \\
\text { December 2021) }\end{array}$ & [40] \\
\hline $\begin{array}{l}\text { Kymriah }^{\circledR} \\
\text { (tisagenlecleucel) }\end{array}$ & $\begin{array}{l}\text { - CED: health technology reassessment based on } \\
\text { additional cohort data } \\
\text { - Outcomes-based rebates linked to IPD offered to } \\
\text { statutory health insurance companies }\end{array}$ & $\begin{array}{l}\text { - CED based on data from final } 5 \text {-year follow-up data from the } \\
\text { ELIANA study (to be submitted by } 1 \text { September 2023) } \\
\text { - Rebates based on survival }\end{array}$ & {$[41,42]$} \\
\hline $\begin{array}{l}\text { Yescarta }^{\circledR} \text { (axicabtagene } \\
\text { ciloleucel) }\end{array}$ & $\begin{array}{l}\text { - CED: health technology reassessment based on } \\
\text { additional cohort data } \\
\text { - Outcomes-based rebates linked to IPD offered to } \\
\text { statutory health insurance companies }\end{array}$ & $\begin{array}{l}\text { - CED based on data from final } 5 \text {-year follow-up data of the } \\
\text { ZUMA-1 study (to be submitted by } 15 \text { May 2022) } \\
\text { - Rebates based on survival }\end{array}$ & {$[43,44]$} \\
\hline $\begin{array}{l}\text { Zolgensma }^{\circledR} \\
\text { (onasemnogene } \\
\text { abeparvovec) }\end{array}$ & $\begin{array}{l}\text { Outcomes-based rebates linked to IPD offered to } \\
\text { statutory health insurance companies }\end{array}$ & $\begin{array}{l}\text { - Rebates of up to } 100 \% \text { based on several patient-relevant } \\
\text { outcomes (not specified further in publicly available sources) } \\
\text { - Potentially using data from RESTORE (a global registry based } \\
\text { on existing country registries) }\end{array}$ & [45-47] \\
\hline $\begin{array}{l}\text { Zynteglo }^{\circledR} \text { (betibeglogene } \\
\text { autotemcel) }\end{array}$ & $\begin{array}{l}\text { - CED: health technology reassessment based on } \\
\text { additional cohort data } \\
\text { - Outcomes-based agreement linked to IPD offered to } \\
\text { statutory health insurance companies }\end{array}$ & $\begin{array}{l}\text { - CED based on long-term follow-up data from HGB-207 and } \\
\text { HGB-212 studies and 5-year follow-up data from the LTF-303 } \\
\text { study (to be submitted by } 15 \text { May 2025) } \\
\text { - Outcomes-based agreement based on transfusion } \\
\text { independence }\end{array}$ & {$[46,48]$} \\
\hline
\end{tabular}

long-term efficacy and safety, additional data collection was necessary to inform health technology reassessment within a maximum of three years [37]. The TC therefore requested that data from all treated French patients are to be collected in a registry, where patient characteristics, effectiveness (in particular its sustainability of effect, iron overload and any organ complications) and long-term tolerance are recorded. The TC also recommended that this data collection effort should be undertaken in collaboration with the French registry of thalassemia patients [38].

\section{Germany}

OBR schemes have historically not been widely adopted in Germany; however, the recent gene therapy launches have seen a shift toward greater application. A key feature of market access in Germany is that new medicines are freely priced for 12 months from the time of launch, and until the national pricing and reimbursement determination has been made [27,39]. A recent development is that manufacturers, in conjunction with payers, have sought OBR approaches based on IPD to enable patient access during this 12-month period (and potentially also beyond). Also, the main national HTA body, the Federal Joint Committee (G-BA), has requested additional data to be submitted to inform health technology reassessments for many of the gene therapies that have launched (see Table 3 for details), effectively representing CED schemes.

All four gene therapies for which G-BA has completed benefit assessments and with reimbursement decisions published have been subject to CED, and required to collect and submit additional cohort data to inform future reassessments (G-BA's decision for Zolgensma ${ }^{\circledR}$ was not published at the time of writing). Also, all four of the most recently launched gene therapies have pursued OBR schemes with different statutory health insurers at launch. 
Table 4. Exemplars of innovative reimbursement mechanisms used for gene therapies in Italy.

\begin{tabular}{|c|c|c|c|}
\hline Therapy & Access scheme used & Nature and source of data collected for access scheme & Ref. \\
\hline Strimvelis ${ }^{\circledR}$ & $\begin{array}{l}\text { Outcomes-based agreement ('payment by results') linked to } \\
\text { IPD }\end{array}$ & $\begin{array}{l}\text { - Payment arrangement with the AIFA, covering all European } \\
\text { patients treated in Italy, includes staggered payments, as well as } \\
\text { refunds if patient has to receive another therapy } \\
\text { - Data collected through the AIFA registry }\end{array}$ & {$[52,53]$} \\
\hline $\begin{array}{l}\text { Kymriah }^{\circledR} \\
\text { (tisagenlecleucel) }\end{array}$ & Outcomes-based payments in installments linked to IPD & $\begin{array}{l}\text { - Payments in three installments: the first at time of treatment, the } \\
\text { subsequent two at } 6 \text { and } 12 \text { months post treatment, subject to } \\
\text { outcomes being achieved and sustained } \\
\text { - Data collected through the AIFA registry }\end{array}$ & [54] \\
\hline $\begin{array}{l}\text { Yescarta }{ }^{\circledR} \\
\text { (axicabtagene } \\
\text { ciloleucel) }\end{array}$ & Outcomes-based payments in installments linked to IPD & $\begin{array}{l}\text { - Payments in three installments: at 180, } 270 \text { and } 365 \text { days post } \\
\text { treatment, subject to outcomes being achieved and sustained } \\
\text { - Data collected through the AIFA registry }\end{array}$ & [55] \\
\hline
\end{tabular}

Both Novartis and Kite/Gilead made interim arrangements for outcomes-based rebates based on survival for Kymriah and Yescarta. These OBR schemes were agreed with several health insurers including two umbrella groups of insurers, Verband der Ersatzkassen (VDEK) and Gesellschaft für Wirtschaftlichkeit und Qualität (GWQ) ServicePlus (covering a total of more than 41 million people [43], or $\sim 60 \%$ of the 70 million Germans insured through statutory health insurance [39]). GWQ ServicePlus has also entered into outcomes-based contracts for Zolgensma and Zynteglo; however, the specifics around outcomes, time horizons and financial implications are confidential. Zynteglo's manufacturer, bluebird bio (MA, USA), proposed payments in five annual instalments of $€ 315,000$, the first at the time of treatment, and the subsequent four payments dependent on transfusion independence [49]. This arrangement is reportedly in place with the health insurer Allgemeine Ortskrankenkassen Krankenkassen (AOK) Rheinland/Hamburg [48,50].

Italy

The Italian experience with OBR is longer and more prolific than in most other European countries. The Italian Medicines Agency (AIFA) is the main regulatory and HTA authority in Italy, and in 2005, it established the AIFA registry, which among other things has served as a vehicle for OBR. Since its inception, a multitude of OBR schemes have implemented (particularly in oncology), with many of the schemes being based on retrospective rebates or on manufacturers providing a certain number of cycles for free (to identify responders) [51]. Table 4 below details OBR schemes in place for the gene therapies in scope.

The launch of Kymriah and Yescarta was interesting in the Italian perspective, as it saw AIFA depart from their previous use of outcomes-based rebates, to apply outcomes-based payments in installments. The official AIFA documents do not disclose what outcome(s) trigger the installments; however, it is notable that for Yescarta the first payment is at 180 days after administration, whereas for Kymriah the first payment is at the time of administration [54-57]. This may open for a scenario where no payment is made for Yescarta unless the agreed outcome(s) have been achieved and sustained through the first 6 months after administration.

Similarly as in France, AIFA facilitates reimbursed early access (before marketing authorization and/or reimbursement determination) through the so-called Law 648 list [58]. Zolgensma was approved for coverage through Law 648 in September 2020 [59]; however, it is not clear from sources in the public domain whether AIFA has tied this to data collection requirements.

\section{Spain}

Only Kymriah and Yescarta have had reimbursement opinions published by the Inter-Ministerial Pricing Committee, which is the key national authority for pricing and reimbursement decisions in Spain [60]. The launch of Kymriah and Yescarta marked a departure from Spain's traditional approach to pricing and reimbursement, i.e., international and domestic reference pricing [61]. The two gene therapies were used to pilot a new data collection and management system for the Spanish National Health Service called Valtermed [62,63]. The Valtermed registry system is designed to collect real-world evidence (RWE) from clinical practice through a web-based tool to reduce the uncertainty associated with new therapies and the benefit observed in Spanish patients [64,65]. Interestingly, Kymriah and Yescarta were reimbursed subject to OBR schemes of payments in installments tied to IPD on key outcomes (see Table 5), similarly as in Italy. 
Table 5. Exemplars of innovative reimbursement mechanisms used for gene therapies in Spain.

\begin{tabular}{|c|c|c|c|}
\hline Therapy & Access scheme used & Nature and source of data collected for access scheme & Ref. \\
\hline $\begin{array}{l}\text { Kymriah }^{\circledR} \\
\text { (tisagenlecleucel) }\end{array}$ & Outcomes-based payments in installments linked to IPD & $\begin{array}{l}\text { - Complete response } \\
\text { - Payments in two installments: one at the time of treatment, and } \\
\text { a second payment at } 18 \text { months, linked to response } \\
\text { - Data collected through Valtermed }\end{array}$ & [66] \\
\hline $\begin{array}{l}\text { Yescarta }{ }^{\circledR} \\
\text { (axicabtagene } \\
\text { ciloleucel) }\end{array}$ & Outcomes-based payments in installments linked to IPD & $\begin{array}{l}\text { - Survival } \\
\text { - Payments in two installments, linked to survival } \\
\text { - Data collected through Valtermed }\end{array}$ & [67] \\
\hline
\end{tabular}

Table 6. Exemplars of innovative reimbursement mechanisms used for gene therapies in England.

\begin{tabular}{|c|c|c|c|}
\hline Therapy & Access scheme used & Nature and source of data collected for access scheme & Ref. \\
\hline $\begin{array}{l}\text { Kymriah }^{\circledR} \\
\text { (tisagenlecleucel) }\end{array}$ & $\begin{array}{l}\text { CED: health technology reassessments after } 5 \text { years } \\
\text { (in 2023) }\end{array}$ & $\begin{array}{l}\text { - Several outcomes considered, however, key uncertainties include overall } \\
\text { survival and the proportion of patients who go on to have a stem cell } \\
\text { transplant or require intravenous immunoglobulin after treatment } \\
\text { - Real-world data collected through SACT dataset } \\
\text { Follow-up data from the JULIET, Schuster, ELIANA, ENSIGN and B2101J } \\
\text { studies }\end{array}$ & {$[70,71]$} \\
\hline $\begin{array}{l}\text { Yescarta }{ }^{\circledR} \\
\text { (axicabtagene } \\
\text { ciloleucel) }\end{array}$ & $\begin{array}{l}\text { CED: health technology reassessments after } 5 \text { years } \\
\text { (in 2023) }\end{array}$ & $\begin{array}{l}\text { - Several outcomes considered, but a key uncertainty is with regards to } \\
\text { survival and its impact on cost-effectiveness } \\
\text { - Real-world data collected through SACT dataset } \\
\text { - Follow-up data from the ZUMA-1 study }\end{array}$ & [72] \\
\hline
\end{tabular}

Several other therapies have since been included in the Valtermed system since its inception; however, none of these are cell or gene therapies.

\section{The United Kingdom (England)}

In England, Kymriah and Yescarta were assessed by the National Institute for Health and Care Excellence (NICE), and found to have incremental cost-effectiveness ratios ranging between $£ 42,991-£ 55,403$ per quality-adjusted life year (QALY) for Kymriah in diffuse large B-cell lymphoma [68], more than $£ 30,000$ per QALY for Kymriah in

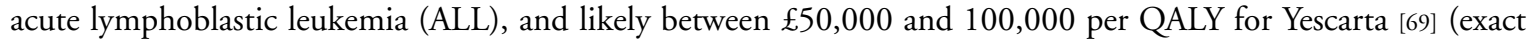
results are considered confidential in nature, thus not reported). Both therapies are reimbursed through the Cancer Drugs Fund (CDF), on the condition of collecting and submitting additional data for the purposes of a future reimbursement decision and price reassessment [70-72], as detailed in Table 6. The CDF is a cancer-specific funding source that enables access to drugs for which there is plausible potential that they could satisfy the criteria for routine commissioning, but where there is significant remaining clinical uncertainty [73]. A standard requirement for funding through the CDF is the collection of RWE through the Systemic Anti-Cancer Therapy (SACT) dataset.

The primary data sources informing the reassessment for Kymriah and Yescarta (scheduled for 2023, after 5 years) are the follow-up data from the ongoing trials, together with RWE captured in the SACT dataset [70,72].

The combination of long-term follow-up data from the clinical studies with RWE from use in clinical practice allows the reassessment to more robustly establish the long-term efficacy (through the trial follow-up data) as well as the (short-term) real-world effectiveness in the English setting.

\section{The USA}

The American healthcare system is highly fragmented, with a wide variety of public and private health insurers. This makes for a more complex environment than in European countries, where there tends to be a single, national health insurance system that undertakes HTAs and decides on how reimbursement and patient access is to be managed.

Thus, in the USA, there is a variety of organizations making decisions about which treatments they will provide health insurance coverage for, and under what conditions. The Institute for Clinical and Economic Review (ICER) assessed Kymriah and Yescarta and found that their incremental cost-effectiveness ratios were \$45,871 per QALY for Kymriah (in ALL), and $\$ 136,078$ per QALY for Yescarta (in B-cell lymphoma) [74,75]. Considerations around 
Table 7. Exemplars of innovative payment mechanisms used for gene therapies in the USA.

\begin{tabular}{|lll|}
\hline $\begin{array}{l}\text { Therapy } \\
\text { Kymriah }{ }^{\circledR} \\
\text { (tisagenlecleucel) }\end{array}$ & $\begin{array}{l}\text { Access scheme used } \\
\text { Outcomes-based payment offered to healthcare providers } \\
\text { (e.g., hospitals) for ALL patients based on IPD }\end{array}$ & $\begin{array}{l}\text { - No invoice for ALL patients who do not achieve response within } \\
30 \text { days } \\
\text { - Data collected at hospital level }\end{array}$ \\
\hline $\begin{array}{l}\text { Luxturna }{ }^{\circledR} \text { (voretigene } \\
\text { neparvovec) }\end{array}$ & $\begin{array}{l}\text { - Outcomes-based rebates (offered to payers) based on IPD } \\
- \text { Pilot of payments in installments proposed to CMS }\end{array}$ & $\begin{array}{l}\text { - Rebates informed by FST testing scores in the short (30-90 days) } \\
\text { and longer term (30 months) } \\
\text { - Payments in installments (as proposed to CMS) are not linked to } \\
\text { outcomes, i.e., it is a purely financial measure to manage } \\
\text { short-term budget impact }\end{array}$ \\
\hline $\begin{array}{l}\text { Zolgensma }{ }^{\circledR} \\
\text { (onasemnogene } \\
\text { abeparvovec) }\end{array}$ & $\begin{array}{l}\text { A variety of payment schemes offered to payers, including } \\
\text { payments in installments and outcomes-based rebates based } \\
\text { on IPD }\end{array}$ & $\begin{array}{l}\text { - Outcomes-based agreement over } 5 \text { years (no further detail } \\
\text { offered) } \\
\text { - Payments in installments are not (necessarily) linked to } \\
\text { outcomes, i.e., it can be a purely financial measure to manage } \\
\text { short-term budget impact }\end{array}$ \\
\hline ALL: Acute lymphoblastic leukemia; CMS: Centers for Medicare \& Medicaid Services; FST: Full-field light sensitivity threshold; IPD: Individual patient data.
\end{tabular}

product value and evidence limitations at launch are very much at play also in the USA; however, the management of the resulting decision uncertainty differs.

\section{Use of innovative pricing \& reimbursement schemes}

Table 7 details examples of innovative pricing and reimbursement schemes for gene therapies in the USA.

In the USA, Novartis offers an outcomes-based payment scheme for Kymriah (but only in the ALL indication) based on individual patient response at 30 days, which is operationalized at hospital level [76]. It is up to insurers (commercial or public) to mandate whether providers are required to engage in this scheme.

Novartis stated upon receiving US FDA approval for Kymriah that they had entered into a novel collaboration with the Centers for Medicare \& Medicaid Services (CMS) focused on 'improving efficiencies in current regulatory requirements in order to deliver value-based care and ensure access', and that they were pursuing an outcomes-based approach (based on individual patient performance) to allow for payment only when pediatric and young adult ALL patients respond by the end of the first month [79]. On the same day Kymriah received FDA approval in ALL, CMS and Novartis issued separate statements detailing their commitment to innovative pricing schemes. CMS stated that 'innovative treatments' like Kymriah 'call for innovative payment models and arrangements', using outcomes-based pricing according to clinical outcomes specifically as a potential avenue [80]. Novartis highlighted their collaboration with CMS to pursue outcomes-based pricing for Kymriah [81]; however, an outcomes-based arrangement between CMS and Novartis never materialized. It was, however, adopted as a requirement for reimbursement to providers by other insurers, for example, MassHealth (Massachusetts' Medicaid and Child Health Insurance Program) $[82,83]$.

CMS assessed both CAR-T cell therapies, and recognized the lack of long-term data and the uncertainty in the pivotal trial data, stemming, for example, from limited patient numbers and limited trial duration, in their final (and positive) coverage determination. CMS also considered implementing a CED scheme as a requirement for Medicare coverage; however, also this was abandoned in the final coverage determination [84]. In its reasoning for not adopting the CED, CMS cited the existing FDA's Risk Evaluation Mitigation Strategy program (ensuring effective management of cytokine release syndrome and neurological toxicities [85-88]), other ongoing trials, as well as the great unmet need and lack of therapeutic alternatives [89].

Spark Therapeutics also followed an innovative payment approach for Luxturna ${ }^{\circledR}$. It reached an agreement with Harvard Pilgrim to use outcomes-based rebates, tied to short- and long-term performance on full-field light sensitivity threshold testing scores $[77,90]$. In order to ensure short-term affordability on the hospital level, Spark contracted directly with insurers for payments for Luxturna to avoid hospitals having to purchase a very expensive therapy and then wait to be reimbursed by insurers (so-called 'buy and bill'). In addition, Spark proposed a scheme using payments in installments over several years to CMS [77].

AveXis/Novartis pursued innovative payment mechanisms in their launch of Zolgensma, including a variety of solutions, for example, outcomes-based rebates, or payments in installments (not linked to outcomes) over a period of 5 years [78]. Insurers Cigna and Harvard Pilgrim are among those involved in discussions with AveXis/Novartis [78], and MassHealth has reportedly also adopted Zolgensma using outcomes-based rebates of up to $100 \%$ (based on IPD) over a period of 5 years [91]. 
Table 8. Comparison of innovative payment mechanisms used for gene therapies across the countries in scope.

\begin{tabular}{|ll|}
\hline Country & Innovative payment schemes employed \\
\hline France & CED scheme on national level based on cohort data (from long-term follow-up of pivotal trials and real-world use) \\
\hline Germany & $\begin{array}{l}\text { CED scheme on national level based on cohort data (from long-term follow-up of pivotal trials) } \\
\text { Rebates (on regional/insurer level) based on IPD }\end{array}$ \\
\hline Italy & Payments in installments based on IPD \\
\hline Spain & Payments in installments based on IPD \\
\hline England & CED scheme on national level based on long-term cohort data (from follow-up of pivotal trials and real-world use) \\
\hline USA & $\begin{array}{l}\text { Rebates (on regional/insurer level) based on IPD } \\
\text { Long-term rebate and payment schemes offered by manufacturers; confirmative data on implementation lacking }\end{array}$ \\
\hline CED: Coverage with evidence development; IPD: Individual patient data.
\end{tabular}

Despite the limited national-level OBR schemes in the USA, there are national-level initiatives in place to collect long-term outcomes data for patients treated with the CAR-T cell therapies, which potentially can be used for future health technology reassessments (essentially retrospective CEDs). For example, the FDA required Novartis and Kite/Gilead to conduct postmarketing, prospective, multicenter, observational studies in (at least) 500 patients (Tescartus ${ }^{\circledR}$ in relapsed or refractory mantle cell lymphoma), 1000 patients (Kymriah in ALL) and 1500 patients (Kymriah and Yescarta in diffuse large B-cell lymphoma) to assess the long-term safety and the risk of all secondary malignancies occurring for 15 years after treatment [16,92-94].

In addition, the Center for International Blood and Marrow Transplant Research (CIBMTR) Registry has expanded its database to include patients treated with CAR-T cell therapies, which the ICER recognized in their HTA of Kymriah and Yescarta as a critically important step to improving the evidence base for such therapies [74]. CIBMTR's dedicated cell therapy registry now serves as an infrastructure for the National Cancer Institute-funded Cellular Immunotherapy Data Resource, and facilitates observational and interventional research through a network of transplant centers, and a clinical outcomes database [95]. CMS recognized the CIBMTR registry's potential role to play also for coverage/payment purposes $[89,96]$, and it was considered a possible candidate as the data collection infrastructure of choice for the CED requirement (which did not materialize) [97].

Although the CIBMTR cell therapy registry appears to have limited application for innovative payment purposes at present, both Novartis and Kite/Gilead use it as a vehicle for complying with FDA's requirement to collect postlaunch RWE on patient outcomes data for Kymriah and Yescarta [98,99]. Although it is not clear exactly what data are collected for each therapy, CIBMTR's data collection form for CAR-Ts enables the structured collection of data on mortality, best response, relapse or progression, peripheral blood count recovery, hematological findings, new malignancies, cell persistence, graft versus host disease, toxicities and infection status [100].

In addition, there are other examples of individual payer organizations' initiatives for collecting RWE for CAR-T cell therapies. For instance, MassHealth's CAR-T Monitoring Program was created as a centralized information source to monitor MassHealth members outcomes, not just at 30 days (e.g., to inform and verify the OBR scheme for Kymriah in ALL), but also every 6 months after treatment [83]. The CAR-T Monitoring Program collects several data parameters including dates of procedures, infusions and admissions; adverse reactions experienced; agents used to treat adverse reactions; and response to therapy (e.g., complete blood count, bone marrow blasts, peripheral blood blasts, platelets and absolute neutrophil counts) [101,102].

\section{Comparing the USA \& European countries}

Table 8 summarizes the main innovative payment approaches used across the USA and European countries for the gene therapies in scope (as per the results detailed above).

\section{Discussion \& conclusion}

The past decade provides an interesting first chapter in the story of gene therapies coming to market in Europe and the USA, and the past 5 years in particular, with an increasing number of therapies launching. Not many years ago, the data uncertainty challenge and its implications for assessing therapy value, and the use of innovative payment mechanisms to overcome them, were topics of a more theoretical nature (with some exceptions). However, recent years have provided more real-world examples, from more countries, to draw learnings from.

Although the challenge around data uncertainty and real-world therapy value applies to all therapies in scope, there is no uniform application of innovative payment mechanisms across the countries or the therapies that 
have launched. This is likely a reflection of the different strategies pursued by manufacturers, and the different preferences and requirements of HTA bodies and reimbursement authorities in different countries. From the manufacturers' side, there has been no lack of initiatives in terms of pursuing innovative payment schemes, and all of the products in scope have been adopted using some form of innovative payment scheme in one or more countries (except Tescartus, which was recently approved in the USA; no further information available at the time of writing). Novartis pursued various innovative arrangements for Kymriah and Zolgensma (the latter together with AveXiS) in the USA and several European countries, Kite/Gilead engaged in different reimbursement schemes based on IPD and cohort-based postlaunch evidence generation linked to the reimbursement of Yescarta in Europe, Spark Therapeutics pursued short- and long-term outcomes-based rebate schemes for Luxturna in the USA and Europe, and bluebird bio is pursuing outcomes-based payments in installments for Zynteglo in Europe [103] (the FDA decision for Zynteglo in the USA is pending).

However, the manufacturers' initiatives have not always been matched by interest from payers. There are several examples, especially in the USA, of manufacturers proposing innovative arrangements; however, where evidence of the implementation of comparable number of innovative schemes appears to be lacking (according to information available in the public domain). Particularly Novartis' pursuit of innovative schemes for Kymriah in its ALL indication in relation to Medicare coverage (where both an outcomes-based rebate scheme based on IPD, and CED scheme based on cohort data were considered, but ultimately not adopted) stands out as an illustration of the divide between the ambition of manufacturers and the appetite of US key market access stakeholders. It should be highlighted that CMS's remit in making coverage determinations for Medicare is different from that of most other HTA bodies and reimbursement authorities, especially those in Europe. CMS's assessment focuses mainly on clinical aspects and the level of unmet need, and although a key requirement for Medicare coverage is that the therapy is 'reasonable and necessary', 'cost is not a factor' in their 'review or decision to cover a particular technology' [104]. This may partly explain CMS's lower appetite for innovative schemes as compared with, for example, their European counterparts, for which cost and value are key decision-making metrics.

The example of Kymriah and Medicare also fits with recent surveys and interviews undertaken with US payers and key market access stakeholders. The results show that although US payers are aware of and open to considering innovative payment and/or financing models, there is a clear preference for simple discounts as a means to manage high-cost therapies (especially in rare diseases) [105,106]. Payers in many countries have historically preferred simple discounts as a means to mitigate uncertainty around long-term product value. However, the benefit of using outcomes-based payments, is that they enable a fair adjustment of payments by addressing data uncertainties, especially around sustainability of effect long term, which is particularly relevant for single-administration gene therapies. One of the takeaways from NICE's regenerative medicines study [107] is that outcomes-based payments increased the probability of therapy being cost-effective but without the risk of eroding product value (unlike upfront discounts).

Some reluctance to adopt OBR schemes can be observed also in Europe, which can be illustrated by bluebird bio's pursuit of outcomes-based payments (based on IPD) in five annual installments for Zynteglo [103]. So far, national reimbursement authorities in France and Germany have assessed Zynteglo for adoption using CED based on cohort data, rather than bluebird bio's proposal (reimbursement decisions in Spain, Italy and England were pending at the time of writing). Also, sales appear to be lagging, despite HTA decisions in France and Germany, with bluebird bio reportedly having sold no units as per their Q3 November filing [50] (the outbreak of COVID-19 will likely also has been an important limiting factor on uptake).

An interesting difference to note in the USA, is the contrast between CMS's approach for Medicare to that of some of the state Medicaid programs. For instance, the willingness of Medicaid programs like MassHealth to engage in innovative payment schemes shows promise for enabling access also for lower-income US patients. However, there are considerable differences between states in terms of Medicaid coverage for gene therapies and how access is managed [108], which may in part be a reflection of the legal/administrative hurdle Medicaid programs face in engaging in such schemes. State Medicaid programs have to apply to CMS for authorization to enter into value-based schemes (as done in, e.g., Arizona, Colorado, Louisiana, Massachusetts and Michigan [109-113]), which, combined with considerable budget constraints, makes for a challenging access environment overall across Medicaid programs.

The launches of Kymriah and Yescarta represent the most widespread application of innovative pricing mechanisms across countries. The experience of the two CAR-T cell therapies illustrates the divide between the USA and European countries in terms of the use of innovative pricing mechanisms. In major European countries, the 
collection of additional data (both from real-world use and continued long-term follow-up of the pivotal trial populations) was mandated by HTA bodies and reimbursement authorities as a condition for access for both CAR-T cell therapies. In the USA, an outcomes-based payment scheme was applied (operationalized at hospital level); however, only in Kymriah's ALL indication, where Novartis will provide the therapy, and only invoice for patients who achieved a response by 30 days.

Another difference worth noting between the schemes applied for CAR-T cell therapies in the USA and major European markets is the time horizon over which the outcomes are collected and used to inform the financial implications. In the European examples, the (confirmed) time horizons for outcome collection span from 12 months (e.g., for the staged payments based on IPD in Italy, and for the annual reassessments of price/reimbursement based on cohort data in France), to 18 months (for the staged payments based on IPD in Spain), and up to 5 years (for the CED scheme informing health technology reassessment in Germany and England). The scheme applied by Novartis for Kymriah in the USA is based on response at 30 days, which is considerably shorter timespan than in any of the major European countries, and is something that clinicians reportedly have questioned the appropriateness of [114]. In addition, the 30 day time horizon in Novartis's scheme in ALL had a relatively modest impact on the incremental cost-effectiveness ratios in ICERs HTA, and in demonstrating long-term value for money (Kymriah's incremental cost-effectiveness ratio in ALL was well within ICER's range of what is considered value for money even without the 30-day OBR scheme) [74].

What constitutes the optimal contract time horizon or scheme structure differs according to the incentive structures in play for different payer segments in different countries. For example, in single-payer countries, like many European countries (France, Italy, Spain and England most notably), the appetite for a long-term scheme may be greater than in multipayer settings (the USA and to some extent Germany), where patients can switch plans, and thereby transfer benefits accrued in the future to another payer. Other key considerations for designing an OBR scheme include: the feasibility of patient follow-up (this should be driven by clinical necessity, not reimbursement considerations); choosing outcomes that are meaningful for payers; the availability of a suitable data collection infrastructure (e.g., registry or database); and the resource requirement on healthcare system staff who collect patient data.

Another potential contributor to the differences in approaches between Europe and the USA in terms of managing the uncertainty around real-world product value is willingness to pay for health improvements. Payers and decision makers in the USA have historically exhibited a higher willingness to pay for healthcare and medicines in general (as we have shown in previous work [115]), which means that what is considered value for money, or a reasonable price to pay for therapeutic innovation is higher. This opens for a greater acceptability of higher prices and/or higher uncertainty around the long-term benefits than in Europe.

The differences between Europe and the USA in the application of innovative payment schemes can also be explained by the differences in how the healthcare systems are structured. In most European countries, there is typically one National Health Service, which insures all (or nearly all) patients. This means that the bargaining power of the healthcare system is greater, and that future health benefits or financial implications would more likely pertain to the same insurer/payer. In the USA, there is a plethora of different insurers/payers, and insured patients can change plans as they see fit, and reportedly $20 \%$ of privately insured patients do so every year [105]. This fluctuation of patients between insurers means that US payers are wary of schemes that include rebates, staged payments or savings from reduced healthcare utilization in the future (as patients may have moved to a different plan), which likely drives the preference for simple discounts. However, and interestingly, there are indications that some US payers do not believe that the current payment model (i.e., full upfront payment with/without simple discounts) is sustainable, and that they are caught in a Catch 22, as long-term (e.g., 24-36 months) payment modalities are viewed as untenable due to patient fluctuation between plans [106].

Another barrier to implementing innovative payment schemes, which is echoed also in Europe, is with regards to the additional administrative burden associated with innovative payment schemes. Results from US payer engagements indicate that many (especially larger health insurers) do not believe that the additional burden is worth it in cases where the overall budget impact is relatively low or manageable as compared with the total budget [105]. However, as the pipeline of new products nearing market grows, so does the cumulative budget impact, and the urgency to change how access to high-value therapeutic innovation is managed.

While data on units sold in the USA versus Europe are scarce in the public domain, revenue data from sales of Yescarta may provide some indication of how uptake differs on the two sides of the Atlantic. According to data from Kite/Gilead for sales of Yescarta in 2019 and the first half of 2020, US sales in the period totaled $\$ 571$ 
million, compared with European sales of $\$ 176$ million in the same period [116,117]. This is a somewhat surprising result considering that the list prices of Yescarta in the USA and in major European countries are in a similar region ( $\$ 373 \mathrm{~K}$ and around $€ 327 \mathrm{~K}$ ), but Europe has a considerably larger population (around 530 million) than the USA (around 330 million) [118]. There are several factors that contribute to these discrepancies across markets, for example, the product is likely be subject to different levels of confidential discounts resulting in revenue differentials, variation in levels of healthcare provider readiness to deliver advanced therapies, off-label use, and importantly, that Yescarta launched earlier in the USA than Europe (providing more time to get established in medical practice). Yet, based on the numbers above, the uptake of Yescarta in Europe may be lagging behind the USA, despite a more widespread use of OBR schemes.

The gene therapies launched in Europe and the USA over the past 5 years serve as interesting exemplars of how different companies and key market access stakeholders have managed the decision uncertainty associated with high-cost breakthrough therapies, supported by limited data at launch. The experience in major European countries indicates an increasing willingness to engage in innovative payment schemes, and while the same is true also in the USA, there seems to be a greater reluctance to adopt such schemes than in Europe. It is encouraging nonetheless seeing more payers on both sides of the Atlantic breaking with the conventional payment paradigm, and pursuing new paths. It will be interesting to continue to follow these developments as more cell and gene therapies launch, many of which have stated ambitions to apply innovative payment schemes as part of the market access strategy [119]. It is our belief that this pursuit will provide more sustainable access to therapeutic innovations in the long term.

\section{Future perspective}

Although the appetite for using innovative payment schemes currently appears lower among payers than among manufacturers, this may not remain the case in the future. As the pipeline of gene therapies approaching market is increasing, so is the awareness and acknowledgment of outcomes-based payment schemes as a potentially effective mechanism to reduce the long-term data uncertainty. We have shown in this paper and past work [8] an increasing trend in terms of stakeholders' willingness to consider and adopt innovative payment solutions, and we believe that this trend will continue into the future.

However, it should be highlighted that innovative payment schemes are a means to an end, and should only be applied in circumstances where there is scope for such mechanisms to effectively reduce decision uncertainty, so that the probability of long-term cost-effectiveness can be improved. For conventional medicines, with repeated administrations and smaller incremental improvements in health, there may be less need for innovative approaches; however, for one-off therapies with potentially curative benefits, such payment schemes have the potential to ensure greater access and reward for therapeutic innovation.

A limitation of this research is the availability of data in the public domain to enable thorough cross-country comparisons of gene-therapy uptake and correlation with the degree of implementation of OBR mechanisms.

\section{Financial \& competing interests disclosure}

The authors have no relevant affiliations or financial involvement with any organization or entity with a financial interest in or financial conflict with the subject matter or materials discussed in the manuscript. This includes employment, consultancies, honoraria, stock ownership or options, expert testimony, grants or patents received or pending, or royalties.

No writing assistance was utilized in the production of this manuscript.

\section{Open access}

This work is licensed under the Attribution-NonCommercial-NoDerivatives 4.0 Unported License. To view a copy of this license, visit http://creativecommons.org/licenses/by-nc-nd/4.0/ 
Executive summary

Background \& methods

- Outcomes-based payment schemes are well suited to reduce payers' decision uncertainty and increase the probability of cost-effectiveness for single-administration (gene) therapies launching with long-term health claims and limited clinical data at launch.

- Our targeted evidence review of secondary sources from the public domain provides a collection of exemplars (as per the final half of 2020) of real-world, cross-country learnings about market access approaches for high-cost, gene therapies with data uncertainty at launch.

Findings and Europe versus USA comparison

- The past 5 years has shown an increase in the application of innovative payment mechanisms for gene therapies; however, the types of schemes applied vary between the USA and European countries:

- European countries exhibit a greater appetite for long-term (12 months or longer) outcomes-based schemes (based both on individual patient data and cohort data) than the USA.

- In the USA, there is a greater preference for simple discounts, although outcomes-based rebates based on short-term (30-day) outcomes are in operation (long-term schemes have been offered by manufacturers, but confirmatory data on implementation is lacking).

- Differences between European countries and the USA may be driven by several factors:

- Higher US willingness to pay for health improvements (and thus willingness to accept long-term decision uncertainty) than in European countries.

- Single-payer systems (e.g., European countries) safeguard that future health benefits and/or savings would pertain to the same payer; the USA is a multipayer system, where patients can move between insurers (payers), thus disincentivizing the use of long-term schemes.

Conclusions

- Key considerations for designing outcomes-based payment schemes include:

- The incentive structures in play for different payer segments in different countries (e.g., single- vs multi-payer systems and the impact on choice of time horizon).

- The feasibility of patient follow-up (this should be driven by clinical necessity, not reimbursement considerations).

- Choosing outcomes that are meaningful for payers.

- The availability of a suitable data collection infrastructure (e.g., registry or database).

- The resource requirement on the healthcare staff who will be in charge of collecting and recording patient data.

- Innovative payment schemes are a means to an end, and should only be applied in circumstances where there is scope for such mechanisms to effectively reduce decision uncertainty, so that the probability of long-term cost-effectiveness can be improved

- For conventional medicines, with repeated administrations and incremental improvements in health, there may be less need for innovative approaches; however, for one-off therapies with potentially curative benefits, such payment schemes can make a real difference.

\section{References}

Papers of special note have been highlighted as: $\bullet$ of interest; $\bullet \bullet$ of considerable interest

1. Alliance for Regenerative Medicine (ARM). Getting ready: recommendations for timely access to advanced therapy medicinal products (ATMPs) in Europe. (2019). http://alliancerm.org/wp-content/uploads/2019/07/ARM-Market-Access-Report-FINAL.pdf

2. Hettle R, Corbett M, Hinde $S$ et al. The assessment and appraisal of regenerative medicines and cell therapy products: an exploration of methods for review, economic evaluation and appraisal. Health Technol. Assess. 21(7), 1-204 (2017).

3. Jönsson B, Hampson G, Michaels J, Towse A, Von Der Schulenburg JG, Wong O. Advanced therapy medicinal products and health technology assessment principles and practices for value-based and sustainable healthcare. Eur. J. Health Econ. 20(3), 427-438 (2019).

- Outlines challenges and potential solutions to the decision uncertainty presented by high-value cell and gene therapies in the US context.

4. Marsden G. Towse A. Pearson S.D. Dreitlein B. Henshall C. Gene therapy: understanding the science, assessing the evidence, and paying for value. (2017). http://www.ohe.org/publications/gene-therapy-understanding-science-assessing-evidence-and-paying-value

-• Overview of different approaches to managing the decision uncertainty related to cell and gene therapies.

5. Massachusetts Institute of Technology NEWDIGS - Financing and Reimbursement of Cures in the US (FoCUS) . White paper: Precision financing solutions for durable/potentially curative therapies. (2019). https://newdigs.mit.edu/sites/default/files/MIT\%20FoCUS\%20Precision\%20Financing\%202019F201v023.pdf 
6. Crabb N. Stevens A. Exploring the assessment and appraisal of regenerative medicines and cell therapy products. National Institute for Health and Care Excellence (NICE). (2016). http://www.nice.org.uk/media/default/about/what-we-do/science\%20policy\%20and\%20 research/regenerative-medicine-study-march2016-2.pdf

7. Jørgensen J, Kefalas P. Annuity payments can increase patient access to innovative cell and gene therapies under England's net budget impact test. J. Mark. Access Health Policy 5(1), 1355203 (2017).

8. Jørgensen J, Hanna E, Kefalas P. Outcomes-based reimbursement for gene therapies in practice: the experience of recently launched CAR-T cell therapies in major European countries. J. Mark. Access Health Policy 8(1), 1715536 (2020).

- Shows the approaches taken by health authorities in different major European countries in reimbursing Kymriah ${ }^{\circledR}$ and Yescarta ${ }^{\circledR}$.

9. Andersson E, Svensson J, Persson U, Lindgren P. Risk sharing in managed entry agreements: a review of the Swedish experience. Health Policy 124(4), 404-410 (2020).

10. Dabbous M, Chachoua L, Caban A, Toumi M. Managed entry agreements: policy analysis from the European perspective. Value Health 23(4), 425-433 (2020).

11. Kim AE, Choi DH, Chang J, Kim SH. Performance-based risk-sharing arrangements (PBRSA): is it a solution to increase bang for the buck for pharmaceutical reimbursement strategy for our nation and around the world? Clin. Drug Investig. 40(12), 1107-1113 (2020).

12. Michelsen S, Nachi S, Van Dyck W, Simoens S, Huys I. Barriers and opportunities for implementation of outcome-based spread payments for high-cost, one-shot curative therapies. Front. Pharmacol. 11, 594446 (2020).

13. Pauwels K, Huys I, Vogler S, Casteels M, Simoens S. Managed entry agreements for oncology drugs: lessons from the European experience to inform the future. Front. Pharmacol. 8, 171 (2017).

14. Picecchi D, Bertram K, Brücher D, Bauer M. Towards novel reimbursement models for expensive advanced therapy medicinal products (ATMPs). Swiss Med. Wkly. 150, w20355 (2020).

15. European Medicines Agency (EMA). Strimvelis - EPAR. (2016). http://www.ema.europa.eu/en/medicines/human/EPAR/strimvelis

16. European Medicines Agency (EMA). May 1, 2018 Approval Letter - Kymriah. (2018). http://www.fda.gov/media/112803/download

17. European Medicines Agency (EMA) Kymriah - EPAR. (2018). http://www.ema.europa.eu/en/medicines/human/EPAR/kymriah

18. Food and Drug Administration (FDA) August 30, 2017 Approval Letter - KYMRIAH. 2017 http://www.fda.gov/vaccines-blood-biologics/cellular-gene-therapy-products/kymriah-tisagenlecleucel

19. European Medicines Agency (EMA). Yescarta - EPAR. (2018). http://www.ema.europa.eu/en/medicines/human/EPAR/yescarta

20. Food and Drug Administration (FDA). Yescarta (axicabtagene ciloleucel). (2017). http://www.fda.gov/vaccines-blood-biologics/cellular-gene-therapy-products/yescarta-axicabtagene-ciloleucel

21. European Medicines Agency (EMA). Luxturna - EPAR. (2018). http://www.ema.europa.eu/en/medicines/human/EPAR/luxturna

22. Food and Drug Administration (FDA). Luxturna. (2017). http://www.fda.gov/vaccines-blood-biologics/cellular-gene-therapy-products/luxturna

23. European Medicines Agency (EMA). Zynteglo - EPAR. (2019). http://www.ema.europa.eu/en/medicines/human/EPAR/zynteglo

24. European Medicines Agency (EMA). Zolgensma - EPAR. (2020). http://www.ema.europa.eu/en/medicines/human/EPAR/zolgensma

25. Food and Drug Administration (FDA). Zolgensma. (2019). https://www.fda.gov/vaccines-blood-biologics/zolgensma

26. Food and Drug Administration (FDA). Tecartus (brexucabtagene autoleucel). (2020). http://www.fda.gov/vaccines-blood-biologics/cellular-gene-therapy-products/tecartus-brexucabtagene-autoleucel

27. Jørgensen J, Kefalas P. Reimbursement of licensed cell and gene therapies across the major European healthcare markets. J. Mark. Access Health Policy 3, (2015).

28. Privolnev Y. Webster R. CAR T-cell therapies in the EU5: what can we expect from payers? (2019). http://www.cellandgene.com/doc/car-t-cell-therapies-in-the-eu-what-can-we-expect-from-payers-0001

29. Rémuzat C, Toumi M, Jørgensen J, Kefalas P. Market access pathways for cell therapies in France. J. Mark. Access Health Policy 3, (2015).

30. Ministère des Solidarité et de la Santé ATU: autorisations temporaires d'utilisation. (2019) https://solidarites-sante.gouv.fr/ministere/acteurs/instances-rattachees/article/atu-autorisations-temporaires-d-utilisation

31. Ministère des Solidarité et de la Santé Autorisations temporaires d'utilisation (ATU). (2019) https://solidarites-sante.gouv.fr/soins-et-m aladies/medicaments/professionnels-de-sante/autorisation-de-mise-sur-le-marche/article/autorisations-temporaires-d-utilisation-atu

32. Agence nationale de sécurité du médicament et des produits de santé (ANSM) Autorisations temporaires d'utilisation (ATU). (2019) http://www.ansm.sante.fr/Activites/Autorisations-temporaires-d-utilisation-ATU/Qu-est-ce-qu-une-autorisation-temporaire-d-utilisati on/(offset) $/ 0$

33. Haute Autorité de Santé (HAS) Commission de la transparence - Avis 12 décembre 2018 - tisagenlecleucel. (2018) http://www.has-sante.fr/upload/docs/application/pdf/2018-12/kymriah_ldgcb_pic_ins_avis3_ct17238.pdf

34. Haute Autorité de Santé (HAS) Commission de la transparence - Avis 5 décembre 2018 - axicabtagene ciloleucel. (2018) http://www.has-sante.fr/upload/docs/application/pdf/2018-12/yescarta_pic_ins_avis3_ct17214.pdf 
35. Agence technique de l'information sur l'hospitalisation Campagne tarifaire 2019 - Nouveaux Recueils - Traitements de type CAR-T cells. (2019) http://www.atih.sante.fr/sites/default/files/public/content/3595/notice_technique_atih-371-6-2019_car-t-cells.pdf

36. Observatoire du Médicament des Dispositifs médicaux et de l'Innovation Thérapeutique (OMEDIT) Ile de France Yescarta. (2019) http://www.omedit-idf.fr/medicaments-princeps/yescarta/

37. Haute Autorité de Santé (HAS) Zynteglo -thalassaemia - opinions on drugs. (2020) http://www.has-sante.fr/jcms/p_3165706/en/zynteglo

38. Haute Autorité de Santé (HAS) Commission De La Transparence Avis 18 Mars 2020 - bétibéglogène autotemcel Zynteglo 1,2 - 20×106 cellules/ml, dispersion pour perfusion - Première évaluation. (2020) http://www.has-sante.fr/upload/docs/evamed/CT-18061_ZYNTEGLO_PIC_INS_AvisDef_CT18061_EPI659.pdf

39. GKV-Spitzenverband Die gesetzlichen Krankenkassen. (2019) http://www.gkv-spitzenverband.de/krankenversicherung/kv_grundprinzi pien/alle_gesetzlichen_krankenkassen/alle_gesetzlichen_krankenkassen.jsp

40. Gemeinsamer Bundesausschuss (G-BA) Tragende Gründe zum Beschluss des Gemeinsamen Bundesausschusses über eine Änderung der Arzneimittel-Richtlinie (AM-RL): Anlage XII - Nutzenbewertung von Arzneimitteln mit neuen Wirkstoffen nach § 35a SGB V Voretigen Neparvovec. (2019) http://www.g-ba.de/downloads/40-268-6053/2019-10-17_AM-RL-XII_Voretigen-Neparvovec_D-436_TrG.pdf

41. Gemeinsamer Bundesausschuss (G-BA) Tragende Gründe zum Beschluss des Gemeinsamen Bundesausschusses über eine Änderung der Arzneimittel-Richtlinie (AM-RL): Anlage XII - Nutzenbewertung von Arzneimitteln mit neuen Wirkstoffen nach § 35a SGB V Tisagenlecleucel Neubewertung nach Fristablauf: Akute lymphatische B-ZellLeukämie). (2020) http://www.g-ba.de/downloads/40-268-6854/2020-09-17_AM-RL-XII_Tisagenlecleucel_ALL_D-529_TrG.pdf

42. Novartis Novartis Pharma GmbH und GWQ ServicePlus schließen Vertrag über ein innovatives Erstattungsmodell für die CAR-T-Zelltherapie. (2019) http://www.dgap.de/dgap/News/corporate/novartis-pharma-gmbh-und-gwq-serviceplus-schliessen-vertra g-ueber-ein-innovatives-erstattungsmodell-fuer-die-cartzelltherapie/?newsID=1132071

43. Maudit H. Major German payers sign pay for performance agreements on CAR-Ts. (2019) http://www.apmhealtheurope.com/freestory/0/64434/major-german-payers-sign-pay-for-performance-agreements-on-car-ts

44. Gemeinsamer Bundesausschuss (G-BA) Tragende Gründe zum Beschluss des Gemeinsamen Bundesausschusses über eine Änderung der Arzneimittel-Richtlinie (AM-RL): Anlage XII - Beschlüsse über die Nutzenbewertung von Arzneimitteln mit neuen Wirkstoffen nach $\S$ 35a SGB V - Axicabtagen-Ciloleucel. (2019) http://www.g-ba.de/downloads/40-268-5742/2019-05-02_AM-RL-XII_Axicabtagen-Ciloleucel_D-406_D-416_TrG.pdf

45. GWQ ServicePlus AG Vertragsabschluss zwischen AveXis und der GWQ zur erfolgsorientierten Erstattung von Zolgensma ${ }^{\circledR}$. (2020) http://www.gwq-serviceplus.de/aktuelles/presse/2020-04-16-gwq-pm-vereinbarung-gwq-p4p-vertrag-zu-zolgensma_6049

46. GWQ ServicePlus AG Pay-for-Performance-Vertrag für das teuerste Medikament der Welt. (2020) http://www.gwq-serviceplus.de/aktuelles/aktuelle-kasseninfo/02_Patent_03

47. Novartis AveXis receives EC approval and activates "Day One" access program for Zolgensma ${ }^{\circledR}$, the only gene therapy for spinal muscular atrophy (SMA). (2020) http://www.novartis.com/news/media-releases/avexis-receives-ec-approval-and-activates-\%22day-on e\%22-access-program-zolgensma-only-gene-therapy-spinal-muscular-atrophy-sma

48. bluebird bio bluebird bio startet in Deutschland mit der weltweit ersten Markteinführung der Gentherapie Zynteglo(TM) (autologe CD34+-Zellen, die für das BA-T87Q-Globin-Gen kodieren). (2020) http://www.presseportal.de/pm/133038/4490221

49. bluebird bio bluebird bio announces launch in Germany of Zynteglo ${ }^{T M}$ (autologous CD34+ cells encoding $\beta A$-T87Q-globin gene) gene therapy for patients 12 years and older with transfusion-dependent $\beta$-thalassemia who do not have $\beta^{\circ} / \beta 0$ genotype. (2020) http: //investor.bluebirdbio.com/news-releases/news-release-details/bluebird-bio-announces-launch-germany-zynteglotm-autologous-cd34

50. Mast J. bluebird spins itself into two companies, severing gene therapy and cancer units. (2020) https://endpts.com/bluebird-spins-itself-into-two-companies-severing-gene-therapy-and-cancer-units/

51. Montilla S, Xoxi E, Russo P, Cicchetti A, Pani L. Monitoring registries at Italian Medicines Agency: fostering access, guaranteeing sustainability. Int. J. Technol. Assess. Health Care 31(4), 210-213 (2015).

52. Chalmers M. Ismailoglu I. Ali O. Innovative payment models:do cutting-edge one-time treatments need equally innovative outcomes or annuity based payment models? (2018) http://www.ispor.org/docs/default-source/presentations/1434.pdf?sfvrsn=9e435b48_1

53. Agenzia Italiana del Farmaco (AIFA) Determina 26 luglio 2016 - Regime di rimborsabilita’ e prezzo di vendita del medicinale per uso umano Strimvelis. (Determina n. 1028/2016). (16A05546). (2016) http:

//www.aifa.gov.it/documents/20142/241028/Determina_n._1028-2016_del_26.07.2016.pdf/e1bfca67-3a3b-ec57-eef4-4a3eebf3844b

54. Agenzia Italiana del Farmaco (AIFA) Regime di rimborsabilita' e prezzo del medicinale per uso umano «Kymriah». (Determina n. 1264/2019). (19A05147) (GU Serie Generale n.188 del 12-08-2019). (2019) http://www.gazzettaufficiale.it/eli/id/2019/08/12/19A05147/SG

55. Agenzia Italiana del Farmaco (AIFA) Determina 4 novembre 2019 Regime di rimborsabilita' e prezzo del medicinale per uso umano «Yescarta». (Determina n. DG/1643/2019). (19A06932) - (GU n.264 del 11-11-2019). (2019) http://www.aifa.gov.it/documents/20142/961234/Determina_DG-1643-2019_Yescarta.pdf/26464c52-5e7b-e97d-74d5-f66f69039fa0 
56. Agenzia Italiana del Farmaco (AIFA) AIFA approva la rimborsabilità della prima terapia CAR-T. (2019) http://www.aifa.gov.it/-/aifa-approva-la-rimborsabilita-della-prima-terapia-car-t

57. Agenzia Italiana del Farmaco (AIFA) Attivazione web e pubblicazione schede di monitoraggio - Registro Yescarta. (2019) http://www.aifa.gov.it/web/guest/-/attivazione-web-e-pubblicazione-schede-di-monitoraggio-registro-yescarta

58. Prada M, Bertozzi C, Proietti B, Urbinati D. The Italian 648/96 list: approvals, rejections and methods in AIFA's evaluation process between January 2013 and May 2015. Value Health 18(7), A680 (2015).

59. Agenzia Italiana del Farmaco (AIFA) Ufficio Segreteria Organi Collegiali - Esiti Area Pre-Autorizzazione CTS 16, 17,18 e 23 Settembre 2020. (2020) http://www.aifa.gov.it/documents/20142/1218894/Esiti_CTS_16-17-18_e_23_settembre_2020_URM.pdf/f0416796-d9 5b-c0b6-1fce-1c9b018a5e47

60. Ministerio de Sanidad Consumo y Bienestar Social (MSCBS) Reglamento Interno De La Comisión Interministerial De Precios De Los Medicamentos (CIMP). (2019) http://www.mscbs.gob.es/profesionales/farmacia/pdf/REGLAMENTO_CIMP_30_09_2019.pdf

61. Paris V, Belloni A. Value in pharmaceutical pricing. doi:https://doi.org/10.1787/5k43jc9v6knx-en (2013) (Epub ahead of print).

62. Arganda C. Los protocolos farmacoclínicos de los CART estrenarán el uso de Valtermed. (2019) http://www.diariofarma.com/2019/07/07/los-protocolos-farmacoclinicos-de-los-cart-estrenaran-el-uso-de-valtermed

63. Ministerio de Sanidad Consumo y Bienestar Social (MSCBS) Preguntas Y Respuestas Frecuentes Sobre El Sistema De Información Para Determinar El Valor Terapéutico En La Práctica Clínica Real De Los Medicamentos De Alto Impacto Sanitario Y Económico En El Sistema Nacional De Salud (VALTERMED). (2019) http://www.mscbs.gob.es/profesionales/farmacia/valtermed/docs/VALTERMED_Preguntas_y_Respuestas.pdf

64. Rosa F. Valtermed: la conexión y el registro de resultados clínicos ya es posible. (2019) http://www.diariofarma.com/2019/07/22/valtermed-la-conexion-y-el-registro-de-resultados-clinicos-ya-es-posible

65. Ministerio de Sanidad Consumo y Bienestar Social (MSCBS) Carcedo: "Valtermed permitirá generar información para la toma de decisiones sobre la mejor opción terapéutica para los pacientes". (2019) http://www.mscbs.gob.es/gabinete/notasPrensa.do?id=4697

66. Rosa F. "Hemos co-creado un modelo con el Ministerio para introducir el CAR-T". (2019) http://www.diariofarma.com/2019/04/23/hemos-co-creado-un-modelo-con-el-ministerio-para-introducir-el-car-t

67. Güell O. Las cláusulas secretas de las terapias más caras contra el cáncer. (2019) https://elpais.com/sociedad/2019/11/06/actualidad/1573072029_715286.html\#?ref=rss\&format=simple\&link=link

68. National institute for Health and Care Excellence (NICE) Tisagenlecleucel for treatingrelapsed or refractory diffuse large B-cell lymphoma after 2 or more systemic therapies:technology appraisal guidance 567. (2019) http://www.nice.org.uk/guidance/ta567/resources/tisagenlecleucel-for-treating-relapsed-or-ref ractory-diff use-large-bcell-lymphoma-aft er-2-or-more-systemic-therapies-pdf-82607087377861

69. National institute for Health and Care Excellence (NICE) Axicabtagene ciloleucel for treating diffuse large B-cell lymphoma and primary mediastinal large B-cell lymphoma after 2 or more systemic therapies:technology appraisal guidance 559. (2019) http://www.nice.org.uk/guidance/ta559/resources/axicabtagene-ciloleucel-for-treating-diff use-large-bcell-lymphoma-and-primary-m ediastinal-large-bcell-lymphoma-after-2-or-more-systemic-therapies-pdf-82607030270917

70. National institute for Health and Care Excellence (NICE) Cancer Drugs Fund managed access agreement:tisagenlecleucel for treating relapsed or refractory B-cell acute lymphoblastic leukaemia in people aged up to 25 years [TA554]. (2018) http://www.nice.org.uk/guidance/ta554/resources/managed-access-agreement-december-2018-pdf-6651288397

71. National institute for Health and Care Excellence (NICE) Cancer Drugs Fund:data collection arrangement for the single technology appraisal of tisagenlecleucel for treating relapsed or refractory diffuse large B-cell lymphoma after 2 or more systemic therapies. (2019) http://www.nice.org.uk/guidance/ta567/documents/committee-papers-4

72. National institute for Health and Care Excellence (NICE) Cancer Drugs Fund managed access agreement:axicabtagene ciloleucel for treating diffuse large B-cell lymphoma and primary mediastinal B-cell lymphoma after 2 or more systemic therapies [TA559]. (2019) http://www.nice.org.uk/guidance/ta559/resources/managed-access-agreement-january-2019-pdf-6660053245

73. NHS England Appraisal and funding of cancer drugs from July 2016 (including the new Cancer Drugs Fund):anew deal for patients, taxpayers and industry. (2016) http://www.england.nhs.uk/wp-content/uploads/2013/04/cdf-sop.pdf

74. Institute for Clinical and Economic Review (ICER) Chimeric antigen receptor T-cell therapy for B-cell cancers: effectiveness and value final evidence report. (2018) http://icerorg.wpengine.com/wp-content/uploads/2020/10/ICER_CAR_T_Final_Evidence_Report_032318.pdf

75. Institute for Clinical and Economic Review (ICER) A look at CAR-T therapies. (2018) http://icerorg.wpengine.com/wp-content/uploads/2020/10/ICER_CAR-T_RAAG_032318.pdf

76. Novartis Novartis 2017 US transparency and patient access report. (2018) http://www.novartis.com/sites/www.novartis.com/files/us-transparency-patient-access-report-2017.pdf

77. Spark Therapeutics Spark Therapeutics announces first-of-their-kind programs to improve patient access to LUXTURNA ${ }^{\text {TM }}$ (voretigene neparvovec-rzyl), a one-time gene therapy treatment. (2018) https://sparktx.com/press_releases/spark-therapeutics-announces-first-of-th eir-kind-programs-to-improve-patient-access-to-luxturna-voretigene-neparvovec-rzyl-a-one-time-gene-therapy-treatment/ 
78. Novartis AveXis announces innovative Zolgensma ${ }^{\circledR}$ gene therapy access programs for US payers and families. (2019) http://www.novart is.com/news/media-releases/avexis-announces-innovative-zolgensma-gene-therapy-access-programs-us-payers-and-families

79. Novartis Novartis receives first ever FDA approval for a CAR-T cell therapy, Kymriah(TM) (CTL019), for children and young adults with B-cell ALL that is refractory or has relapsed at least twice. (2017)

http://www.novartis.com/news/media-releases/novartis-receives-first-ever-fda-approval-car-t-cell-therapy-kymriahtm-ctl019-childrenand-young-adults-b-cell-all-refractory-or-has-relapsed-least-twice

80. Centers for Medicare \& Medicaid Services (CMS) CMS: innovative treatments call for innovative payment models and arrangements. (2017) http://www.cms.gov/newsroom/press-releases/cms-innovative-treatments-call-innovative-payment-models-and-arrangements

81. Novartis Novartis receives first ever FDA approval for a CAR-T cell therapy, Kymriah(TM) (CTL019), for children and young adults with B-cell ALL that is refractory or has relapsed at least twice. (2017) http://www.novartis.com/news/media-releases/novartis-receives-first-ever-fda-approval-car-t-cell-therapy-kymriahtm-ctl019-childrenand-young-adults-b-cell-all-refractory-or-has-relapsed-least-twice

82. Margulies R. Perspectives on State and Federal Medicaid Policies Medicaid Landscape: Medicaid approaches to cell and gene therapy coverage and reimbursement. (2019)

http://www.asgct.org/global/documents/ps-day-2-slides/10-ross-margulies-asgct-policy-summit-2019.aspx

83. Outspoken Oncology MassHealth models reimbursement strategy for CAR-T therapies in a value-based program. (2019) http://www.journalofclinicalpathways.com/masshealth-models-how-optimally-reimburse-car-t-therapies-value-based-program

84. Centers for Medicare \& Medicaid Services (CMS) Proposed decision memo for chimeric antigen receptor (CAR) T-cell therapy for cancers (CAG-00451N). (2019)

http://www.cms.gov/medicare-coverage-database/details/nca-proposed-decision-memo.aspx?NCAId=291

85. Food and Drug Administration (FDA) Approved risk evaluation and mitigation strategies (REMS) - Kymriah (tisagenlecleucel) BLA \#125646. (2019) http://www.accessdata.fda.gov/scripts/cder/rems/index.cfm?event=indvremsdetails.page\&rems=368

86. Food and Drug Administration (FDA) Risk evaluation and mitigation strategy (REMS) document - Kymriah (tisagenlecleucel) REMS program. (2019) http://www.accessdata.fda.gov/drugsatfda_docs/rems/Kymriah_2019_06_20_REMS_Full.pdf

87. Food and Drug Administration (FDA) Approved risk evaluation and mitigation strategies (REMS) - Yescarta (axicabtagene ciloleucel) and Tecartus (brexucabtagene autoleucel) BLA \#125703 BLA \#125643. (2020)

http://www.accessdata.fda.gov/scripts/cder/rems/index.cfm?event=IndvRemsDetails.page\&REMS=375

88. Food and Drug Administration (FDA) Risk evaluation and mitigation strategy (REMS) document - Yescarta (axicabtagene ciloleucel) and TECARTUS (brexucabtagene autoleucel) REMS program. (2020) http://www.accessdata.fda.gov/drugsatfda_docs/rems/Yescarta_and_Tecartus_2020_07_24_REMS_Full.pdf

89. Centers for Medicare \& Medicaid Services (CMS) Decision Memo for chimeric antigen receptor (CAR) T-cell therapy for cancers (CAG-00451N). (2019) http://www.cms.gov/medicare-coverage-database/details/nca-decision-memo.aspx?NCAId=291

90. Gene therapy's next installment. Nature Biotechnol. 37(7), 697-697 (2019).https://www.nature.com/articles/s41587-019-0194-z

91. Bebinger M. Mass. outlines deal for a $\$ 2$ million drug: pay only if it works. (2020) http://www.wbur.org/commonhealth/2020/02/07/massachusetts-masshealth-zolgensma-cost-control

92. Food and Drug Administration (FDA) August 30, 2017 Approval Letter - Kymriah. (2017) http://www.fda.gov/media/106989/download

93. Food and Drug Administration (FDA) October 18, 2017 Approval Letter - Yescarta. (2017) http://www.fda.gov/media/108458/download

94. Food and Drug Administration (FDA) July 24, 2020 Approval Letter - Tecartus. (2020) http://www.fda.gov/media/140415/download

95. Center for International Blood \& Marrow Transplant Research (CIBMTR) Kite and the CIBMTR ${ }^{\circledR}$ present positive findings from real-world use of Yescarta ${ }^{\circledR}$ (axicabtagene ciloleucel) in relapsed or refractory large B-cell lymphoma. (2019) http://www.cibmtr.org/ReferenceCenter/NewsReleases/Documents/CIBMTR\%20Kite\%20Press\%20Release\%20FINAL.pdf

96. Institute for Clinical and Economic Review (ICER) A guide to ICER's methods for health technology assessment. (2018) http://icer-review.org/wp-content/uploads/2018/08/ICER-HTA-Guide_082018.pdf

97. Shah J. Achieving sustainable market and patient access: Medicare and Medicaid coverage, reimbursement, and coding issues for CAR-T. (2019) http:

//www.asgct.org/ASGCT/media/about/Approved-Jugna-Shah-from-Nimitt_ASGCT_Final-CAR-T-Presentation-for-Distribution.pdf

98. Center for International Blood \& Marrow Transplant Research (CIBMTR) CIBMTR to track long-term outcomes data for Kymriah ${ }^{\circledR}$ (2018) http://www.cibmtr.org/ReferenceCenter/NewsReleases/Documents/CIBMTR\%20Novartis\%20Press\%20Release\%20FINAL.pdf

99. Center for International Blood \& Marrow Transplant Research (CIBMTR) CIBMTR announces collaboration with Kite to track long-term outcomes data for Yescarta ${ }^{\circledR}$. (2018)

http://www.cibmtr.org/ReferenceCenter/NewsReleases/Documents/MCW__BTMB_CIBMTR\%20Press\%20Release\%20FINAL.pdf 
100. Center for International Blood \& Marrow Transplant Research (CIBMTR) Form 4100 R4.0: cellular therapy essential data follow-up form. (2019) http://www.cibmtr.org/DataManagement/DataCollectionForms/Documents/4100/Rev4.0/4100R4.0EC.pdf

101. MassHealth MassHealth Drug List - Table75: chimeric antigen receptor (CAR)-T immunotherapies. (2020) https://masshealthdruglist.ehs.state.ma.us/MHDL/pubtheradetail.do?id=353

102. MassHealth MassHealth Acute Hospital Carve-Out Drugs List. (2020) https://masshealthdruglist.ehs.state. ma.us/MHDL/pubdownloadpdf welcome.do?docId=266\&fileType=PDF

103. bluebird bio Recoding in Action - Q3 2020 (corporate presentation - September 2020). (2020) http://investor.bluebirdbio.com/static-files/ae77f 100-cde6-4eb3-b4ff-7767f035cc1a

104. Centers for Medicare \& Medicaid Services (CMS) Factors CMS considers in commissioning external technology assessments. (2006) http://www.cms.gov/medicare-coverage-database/details/medicare-coverage-document-details.aspx?MCDId=7\&mcdtypename=Guida nce+Documents\&MCDIndexType $=1 \& \mathrm{bc}=$ AgAEAAAAAAAAAA $\% 3 \mathrm{~d} \% 3 \mathrm{~d} \&$

105. Schmickel B. Perry K. Sanchez H. Francis A. Haber A. Davis C. Plummer B. Frois C. Exploring the truth of reimbursement challenges for cell and gene therapies. (2019) https://trinitylifesciences.com/wp-content/uploads/2019/06/Trinity_Reimbursement_Challenges-6.10.19--1.pdf

106. Faulkner E. Werner M. Falb R. Roadmap for navigating cell and gene therapy value demonstration and reimbursement in U.S. Managed Care. (2020) http://alliancerm.org/wp-content/uploads/2020/05/ARMMonograph2019.pdf

107. National institute for Health and Care Excellence (NICE) Exploring the assessment and appraisal of regenerative medicines and cell therapy products. (2016) http://www.nice.org.uk/media/default/about/what-we-do/science\%20policy\%20and\%20research/regenerativ e-medicine-study-march-2016.pdf

- National Institute for Health and Care Excellence's theoretical exploration of the use of payments in installments ('lifetime leasing') as a means to reduce decision uncertainty.

108. Shupe L. Udeze C. An analysis of healthcare plan CAR T cell coverage criteria for Medicaid beneficiaries. (2020) https://pharmafellows.rutgers.edu/wp-content/uploads/2020/08/2019-an-analysis-of-healthcare-plan-car-t-cell-coverage-criteria-formedicaid-benef iciaries-1.pdf

109. Center for Medicaid and CHIP Services Colorado's State Plan Amendment ( SPA) 18- 0044:approval letter. (2019) http: //www.medicaid.gov/sites/default/files/State-resource-center/Medicaid-State-Plan-Amendments/Downloads/CO/CO-18-0044.pdf

110. Center for Medicaid and CHIP Services Michigan State Plan Amendment (SPA) \#: 18-0009:approval letter (20/10). (2018) https://www.michigan.gov/documents/mdhhs/SPA_18-0009_Approved_654410_7.pdf

111. Center for Medicaid and CHIP Services Louisiana State Plan Amendment (SPA) 19-0029:approval letter. (2020) http://www.medicaid.gov/sites/default/files/State-resource-center/Medicaid-State-Plan-Amendments/Downloads/LA/LA-19-0018.pdf

112. Center for Medicaid and CHIP Services Arizona’s State Plan Amendment (SPA) 19-0004:approval letter. (2020) http://www.azahcccs.gov/Resources/Downloads/MedicaidStatePlan/Amendments/2020/AZSPA_19-0004_VBP_ApprovalPackage.pdf

113. Center for Medicaid and CHIP Services Massachusetts State Plan Amendment (SPA) 19-0001:approval letter. (2019) http: //www.medicaid.gov/sites/default/files/State-resource-center/Medicaid-State-Plan-Amendments/Downloads/MA/MA-19-0001.pdf

114. GlobalData Healthcare Outcome-based contracts viable for Kymriah, but US payers still unsure. (2018) http://www.pharmaceutical-technology.com/comment/outcome-based-contracts-kymriah/

115. Jørgensen J, Kefalas P. A price comparison of recently launched proprietary pharmaceuticals in the UK and the US. J. Mark. Access Health Policy 4, (2016).

116. Gilead Sciences. Gilead Sciences announces fourth quarter and full year 2019 financial results.. (2020). http://www.gilead.com/news-an d-press/press-room/press-releases/2020/2/gilead-sciences-announces-fourth-quarter-and-full-year-2019-financial-results

117. Gilead Sciences Gilead Sciences announces second quarter and first half 2020 financial results. (2020) http://www.gilead.com/news-andpress/press-room/press-releases/2020/7/gilead-sciences-announces-second-quarter-and-first-half-2020-financial-results\#: : text=Yescarta\%20\%C2\%AE\%20(axicabtagene\%20ciloleucel)\%20generated, the\%20continued\%20uptake\%20in\%20Europe.

118. The World Bank World Population Statistics. (2018) https://data.worldbank.org/indicator/SP.POP.TOTL

119. Kelly C. Value-based contracts are evolving:US payers turn to high cost, curative therapies.

(2020). https://invivo.pharmaintelligence.informa.com/IV124597/ValueBased-Contracts-Are-Evolving 
